\title{
Natal signatures of juvenile Coris julis in the Azores: investigating connectivity scenarios in an oceanic archipelago
}

\author{
J. Fontes ${ }^{1, *}$, J. E. Caselle ${ }^{2}$, M. S. Sheehy ${ }^{2}$, R. S. Santos ${ }^{1}$, R. R. Warner ${ }^{2}$ \\ ${ }^{1}$ IMAR/Department of Oceanography and Fisheries, University of the Azores, 9901-862 Horta, Portugal \\ ${ }^{2}$ Marine Science Institute, University of California Santa Barbara, Santa Barbara, California 93106, USA
}

\begin{abstract}
To estimate connectivity between populations, we used trace-element composition in otoliths of the temperate wrasse Coris julis as a proxy for the environmental conditions experienced from hatch to settlement. Recruits collected at different sites in the Azores archipelago (northeastern Atlantic) differed significantly in their natal chemical signatures, and were sufficiently diverse to be separated into in 4 distinct natal types. Types 1 and 4 were both low in $\mathrm{Mg}$ and $\mathrm{Ba}$, although $\mathrm{Mg}$ was dominant in Type 1, and Type 4 was more Ba enriched. Type 2 had high Ba and intermediate Mg concentrations, while Type 3 showed the highest $\mathrm{Mg}$ and intermediate Ba concentrations. We identified at least 2 natal types present in recruits at each site, which suggests multiple larval sources per site. Recruits from 3 sites did not differ greatly in their natal type composition, suggesting a common set of sources, but also limiting our ability to describe meaningful connectivity and dispersal scenarios. In contrast, we found that the prevalent Natal Type 4 was absent at 1 site, suggesting that the source characterized by Natal Type 4 does not contribute to the replenishment of $C$. julis populations at the site. The most striking difference was observed at the smallest scale (10s of kilometers), where we found distinct natal type compositions between north and south shores on the same island, suggesting that these 2 sites have consistent differences in the contribution of specific natal sources. Further, the south shore site had recruits with elevated Mg:Ca concentrations from the otolith core to edge, which suggests that these larvae developed in inshore areas and experienced local retention.
\end{abstract}

KEY WORDS: Otolith chemistry $\cdot$ Otolith core $\cdot$ Fish larvae $\cdot$ Trace element $\cdot$ LA-ICP-MS $\cdot$ Dispersal · Population connectivity

\section{INTRODUCTION}

Many populations of coastal marine species are connected primarily by dispersal during a relatively short pelagic larval phase (i.e. days to months; Hamilton et al. 2008). The degree to which these populations are connected has major implications for population dynamics and persistence, and this remains a major unanswered question for most widespread species with a pelagic larval phase (Warner \& Cowen 2002). Current management efforts, such as the establishment of marine protected areas, are limited by the current paucity of information regarding larval transport processes (Miller \& Shanks 2004, Sale et al. 2005).
Despite increasing numbers of studies attempting to measure larval dispersal directly, it remains very difficult in practice (e.g. Jones et al. 1999, Swearer et al. 1999, Almany et al. 2007), because identifying natal origins of marine fishes is very challenging (Cowen \& Sponaugle 2009). In particular, difficulties in conducting markrecapture studies in marine systems (Thorrold et al. 2001), the limited success associated with the tracking of larvae in situ (Leis \& Carson-Ewart 1998), and high larval mortality rates during dispersal make recovery of tagged individuals particularly difficult (but see Jones et al. 1999, Almany et al. 2007). On the other hand, genetic techniques only offer indirect estimates of dispersal distance and long-term dispersal patterns (Kinlan \& Gaines 
2003). Fortunately, in some cases, the varying physical and chemical characteristics of ambient seawater are reflected in the larval otolith (structures in the inner ears of fishes composed of a calcium carbonate/protein matrix) and are preserved in its structure, forming a permanent record of past environmental conditions experienced by the individual (Campana \& Neilson 1985, Thorrold et al. 1997). Over the past 2 decades several authors have found evidence that larvae growing up in different water masses are likely to produce otoliths of distinct elemental composition (e.g. Swearer et al. 1999, DiBacco \& Levin 2000, Thorrold et al. 2001, Forrester \& Swearer 2002, Miller \& Shanks 2004). Such variations in trace-element compositions of fish otoliths (elemental fingerprints) have been used both to discriminate commercial fish stocks (Campana et al. 1994, Fowler et al. 2005) and to infer migration pathways and environmental conditions experienced by fishes (Thorrold et al. 1997, Jones et al. 1999, Swearer et al. 1999, Secor et al. 2001, Warner et al. 2005, Hamilton et al. 2008, Standish et al. 2008). Emerging work analyzing the otoliths from larval fish sampled prior to dispersal has documented unique elemental signatures among natal sites (Warner et al. 2005, Ruttenberg \& Warner 2006, Standish 2007), demonstrating that otolith elemental signatures have the potential to discriminate the geographic origin of fish, particularly when an atlas of natal otolith chemistry is available (Ruttenberg et al. 2008). When the collection of pre-pelagic larval otoliths is not feasible, it is still possible to compare the elemental signatures at the otolith core of a series of recruits collected across a broad geographic region. This core is formed during the earliest life stage of juvenile fish, and thus a collection of individuals has the potential to characterize the diversity of geographic origins; however, it is very difficult to assign the recruits to a specific geographic location. More importantly, the spatial pattern produced from this analysis can provide information about the extent of mixture among locations and the degree to which different populations receive recruits from different sources (FitzGerald et al. 2004, Ashford et al. 2006, Standish et al. 2008). Such records from fish collected in different areas may yield information about the relative distances larvae have dispersed (Miller \& Shanks 2004).

In the present study, we examined natal elemental signatures in the otolith cores of recruit rainbow wrasse Coris julis to investigate population connectivity/ isolation scenarios in the Azores archipelago. In particular, we analyzed otoliths of recruits from different locations, islands, and offshore reefs throughout the region, and we grouped elemental concentrations at the core to classify distinct natal elemental signature types. We also analyzed the elemental composition from the otolith core to the edge in order to infer shared/similar environments during larval dispersal.

\section{MATERIALS AND METHODS}

Study area and species. The Azores archipelago, in the northeastern Atlantic (bounded by 37 and $40^{\circ} \mathrm{N}, 25$ and $32^{\circ} \mathrm{W}$ ), is composed of 9 volcanic islands and several islets, as well as offshore reefs and seamounts (Fig. 1). Shallow habitat is limited, and the surrounding water is deep. Most of the island shores are exposed, except for some small bays and harbors. Oceanography is influenced by the Gulf Stream, and its southeastern branch generates the eastward-flowing Azores Current (Klein \& Siedler 1989). In general, productivity is low, but localized upwelling associated with island slopes and seamounts can enhance local production (Monteiro et al. 1996, Bashmachnikov et al. 2004, Morato et al. 2008). Sea surface temperature and chlorophyll a concentration are out-of-phase throughout the year, with the highest productivity usually occurring in March when temperature is low. Productivity is typically lowest in August and September (Amorim et al. 2009). The water current patterns result in a complex circulation, high salinity and temperature, and the low nutrient regime that typifies the Azores (Santos et al. 1995).

The Mediterranean rainbow wrasse Coris julis (Linnaeus, 1758; Pisces: Labridae) is a small, moderately short-lived (average 2 to $4 \mathrm{yr}$ ), shallow-water, temperate reef fish, and one of the most abundant species in the Azorean reef fish community (Patzner \& Santos 1993, Afonso 2002). The rainbow wrasse spawns in the water column, releasing planktonic larvae, with a long pelagic larval dispersal stage (up to $46 \mathrm{~d}$; Raventos \& Macpherson 2001, J. Fontes pers. obs.).

Fish collection and sample preparation. Using aquarium dip nets, divers collected approximately 30 recently settled recruits from 1 arbitrarily selected, shallow (10 to $20 \mathrm{~m}$ ) rocky reef from 3 islands (Corvo, Faial [2 sites: Varadouro and Salão], and Santa Maria [Sta. Maria]), and from the top of 2 offshore reefs (Don João de Castro [DJC] and Princesa Alice [P Alice]; Fig. 1). Recruits from P Alice and DJC were collected from the shallowest portion of the reef, at 35 and $25 \mathrm{~m}$, respectively. Most recruits were collected in late August 2004, during a 2 wk research vessel cruise, except at Varadouro, where the analyzed samples were collected on 2 occasions: $1 \mathrm{wk}$ before the cruise and $1 \mathrm{wk}$ after. Captured recruits were transferred to a fine mesh bag and preserved in $96 \%$ ethanol. Fish were then measured to the nearest $0.5 \mathrm{~mm}$ (standard length, SL), and the left sagittal otoliths were removed. Adhering organic tissue was removed with clean paper tissue, and then otoliths were rinsed in triple-distilled water and placed in individual polycarbonate wells in culturing trays, where they air-dried before trays were sealed.

Otoliths were mounted sulcus side down on $20 \times$ $20 \mathrm{~mm}$ plastic slides using low-viscosity epoxy resin 


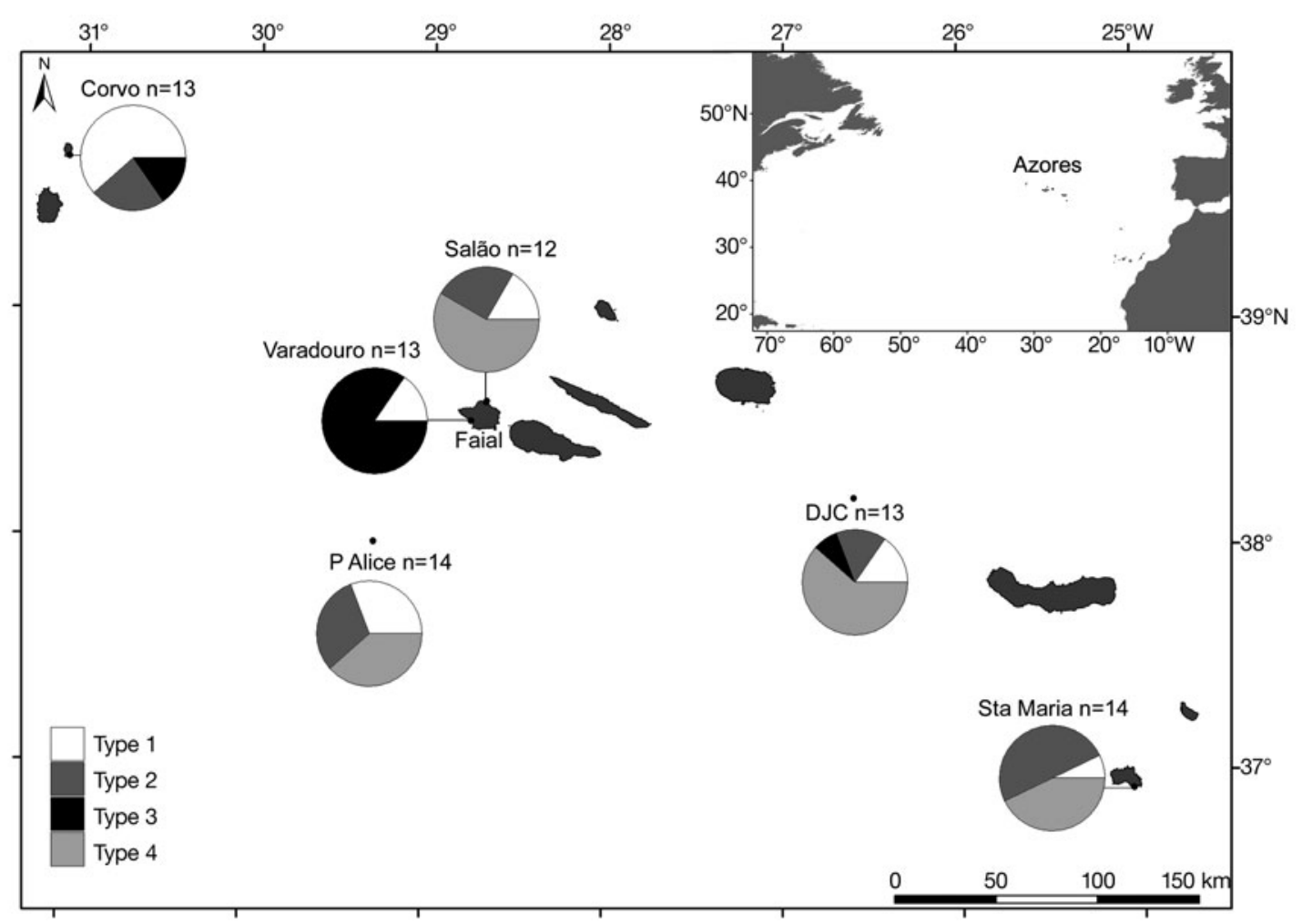

Fig. 1. Coris julis. Map of Azores archipelago and north Atlantic (upper right corner inset), with collection locations. Pie diagrams represent the proportion of natal signature types at each collection location; $\mathrm{n}$ is the total number of samples used in the statistical analysis. Black dots: recruit collection sites, DJC: Don João de Castro, P Alice: Princesa Alice, Sta Maria: Santa Maria

(Buehler Epo-Thin epoxy resin) and were hand-polished to expose the core, daily growth rings, and the settlement mark, using 3 and $9 \mu \mathrm{m} 3 \mathrm{M}$ diamond polishing film, until 10 to $20 \mu \mathrm{m}$ above the visible core. The distance between the polished surface and the core was measured (in microns) using a calibrated $z$-axis on a compound microscope at $400 \times$. The material left above the core prevented losses of core-associated material during the pre-ablation procedure. Contaminants and proteins were removed from the otolith surface prior to analysis using the procedure of Ruttenberg et al. (2005).

Analytical methods. The analytical procedure used to measure the elemental composition of otolith cores and transect pits followed Ruttenberg et al. (2005). We used a Finnigan MAT Element 2 sector field inductively coupled plasma mass spectrometer (ICP-MS) and a VG-UV microprobe Nd:YAG 266 nm laser ablation system. The system was outfitted with a helium carrier gas system in order to increase sensitivity through enhanced transfer of ablated particles to the ICP-MS. Argon gas was used with a microconcentric nebulizer aspirating $1 \% \mathrm{HNO}_{3}$. The helium gas from the laser sample cell and the argon gas from the nebulizer were mixed in a Scott style double pass spray chamber before being introduced to the plasma.
After placing otoliths in the sample cell, the otolith core was located using a $400 \times$ objective and a video imaging system, and we then collected and analyzed 20 sequential pits in a vertical transect over the visually identified core. Each pit consisted of 8 laser pulses of $0.1 \mathrm{~mJ}$ at $3 \mathrm{~Hz}$, and all pits in a given vertical transect were ablated in a single crater ( $30 \mu \mathrm{m}$ in diameter).

Counts were collected for the isotopes ${ }^{24} \mathrm{Mg},{ }^{48} \mathrm{Ca}$, ${ }^{55} \mathrm{Mn},{ }^{56} \mathrm{Fe},{ }^{59} \mathrm{Co},{ }^{63} \mathrm{Cu},{ }^{86} \mathrm{Sr},{ }^{110} \mathrm{Cd},{ }^{138} \mathrm{Ba}$, and ${ }^{208} \mathrm{~Pb}$, and relatively elevated levels of $\mathrm{Mn}$ (at least 3-fold higher than surrounding material) were used to identify otolith cores. This feature has been shown to be an accurate indicator of the location of the natal core of the otolith for Thalassoma bifasciatum (a relative of Coris julis) recruits (e.g. Swearer et al. 1999, Ruttenberg et al. 2005, Hamilton et al. 2008). All elements associated with the core layer $(\mathrm{Mg}, \mathrm{Ca}, \mathrm{Mn}, \mathrm{Fe}, \mathrm{Co}, \mathrm{Cu}, \mathrm{Sr}, \mathrm{Ba}$, and $\mathrm{Pb}$ ) were acquired using medium resolution $(R=$ 3000 , since $\mathrm{Mn}$ is only detectable at medium resolution) and were used to characterize the core elemental composition. After sampling the cores, we also ablated and analyzed the composition of individual pits along a transect stretching from the core to the edge of the otolith (along the longest axis). Each of these pits was sequentially sampled at medium (for $\mathrm{Mn}, \mathrm{Fe}, \mathrm{Co}, \mathrm{Cu}$ ) 
and low $(R=300$, for $\mathrm{Mg}, \mathrm{Ba}, \mathrm{Sr}, \mathrm{Cd}, \mathrm{Pb})$ resolution. The National Institute of Standards aand Technology (NIST) precision estimates and NIST-derived mean analyte:Ca ratios showed very comparable low and medium resolution values for all elements (e.g. no significant difference between NIST low and medium resolution elemental ratios, $p>0.05$ ). Before acquiring data, we pre-ablated the otolith surface using 2 laser pulses to remove any surface contamination.

Calibration. For all elements, the ratio of analyte isotope intensity to ${ }^{48} \mathrm{Ca}$ intensity was used to estimate the analyte:Ca ratio. These ratios were converted to molar ratios based on the isotope ratio mass bias correction calculated from calibration solutions with known analyte:Ca ratios. We analyzed solid glass standard reference material (NIST 612) along with the samples to maintain instrument analytical precision (\%RSD) and detection limits (see Table 1). Detection limits were cal-

Table 1. Coris julis. Estimates of precision and detection limits. Values for \%RSD (\% relative standard deviation) are dimensionless. NIST: National Institute of Standards and Technology. Detection limit values for $\mathrm{Mg}: \mathrm{Ca}$ and $\mathrm{Sr}: \mathrm{Ca}$ are given in mmol $\mathrm{mol}^{-1}$, for $\mathrm{Mn}: \mathrm{Ca}$ and $\mathrm{Ba}: \mathrm{Ca}$ in $\mu \mathrm{mol} \mathrm{mol}{ }^{-1}$. na: not applicable

\begin{tabular}{|c|c|c|c|c|}
\hline & \multicolumn{2}{|c|}{ NIST \%RSD } & \multicolumn{2}{|c|}{ Detection limit } \\
\hline & $\begin{array}{c}\text { Low } \\
\text { resolution }\end{array}$ & $\begin{array}{l}\text { Medium } \\
\text { resolution }\end{array}$ & $\begin{array}{l}\text { Low } \\
\text { resolution }\end{array}$ & $\begin{array}{c}\text { Medium } \\
\text { resolution }\end{array}$ \\
\hline $\mathrm{Mg}: \mathrm{Ca}$ & 0.9 & 2.9 & 0.04 & 0.04 \\
\hline $\mathrm{Mn}: \mathrm{Ca}$ & na & 5.8 & na & 2.44 \\
\hline Ba:Ca & 2.2 & 15.1 & 0.21 & 0.51 \\
\hline $\mathrm{Sr}: \mathrm{Ca}$ & 1.0 & 4.8 & 0.03 & 0.06 \\
\hline
\end{tabular}

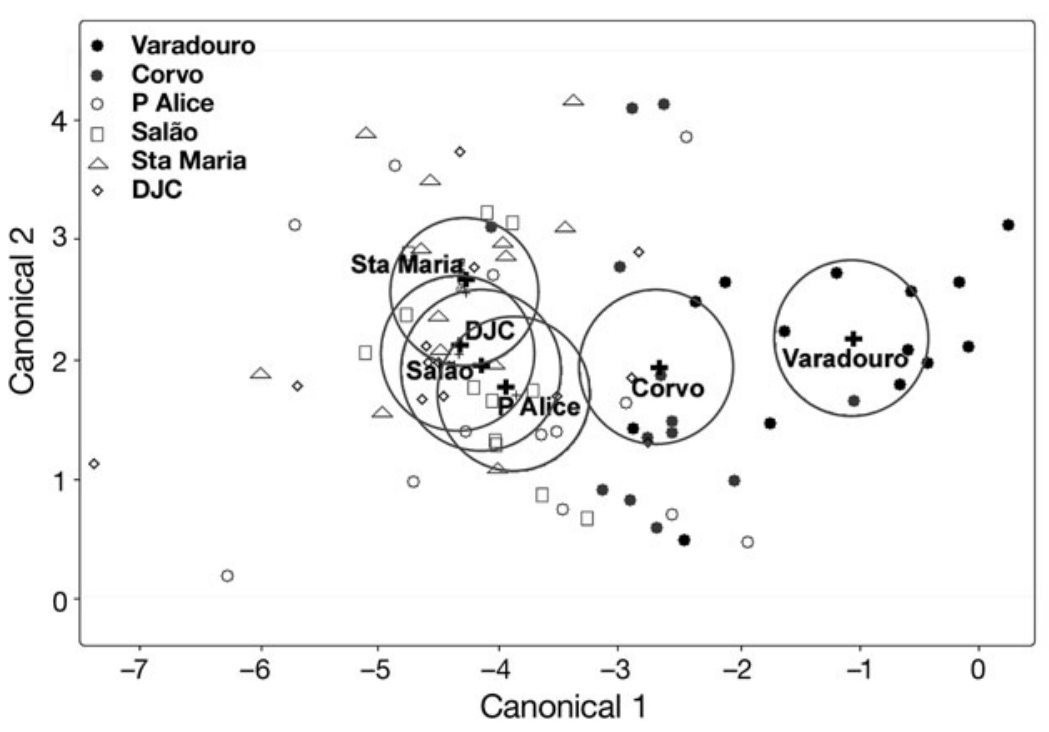

Fig. 2. Coris julis. Discriminant function analysis of otolith cores (each point represents a single core). Plots were generated using $\mathrm{Ba}$ and $\mathrm{Mg}$ concentrations. Sampling sites are shown in Fig. 1. Circle enclosures: $95 \%$ confidence limits for the mean culated as $3 \times \mathrm{SD}$ of blanks $\left(1 \% \mathrm{HNO}_{3}\right)$, expressed as ratios to mean $\mathrm{Ca}$ intensities. Because $\mathrm{Pb}, \mathrm{Fe}, \mathrm{Co}, \mathrm{Cd}$, and $\mathrm{Cu}$ signal strength was low and consistently below detection limits, they were excluded from further analysis.

Statistical analyses. Ba and Mg concentrations were used in the following analysis because they were the 2 elements that showed the most variation among cores or sites. Mn was only used as an indicator of core location, and Sr did not differ significantly among recruit cores from different sites. Samples in which we could not detect a Mn:Ca spike, indicative of natal core, or those where concentrations of $\mathrm{Mg}$ or Ba were below detection limits were excluded from the analysis (11 of the 90 samples processed were excluded, i.e. $12 \%$ ). All data were $\ln$ transformed as necessary to conform to the assumptions of normality.

Multivariate analysis of variance (MANOVA) repeated-measures analysis was used to determine significant differences among locations for multi-elemental fingerprints of natal otoliths, and discriminant function analysis was used to visualize the pattern of a site's natal fingerprints in multivariate space. Recruit 'natal types' for each site were classified by cluster analysis based on Ward's minimum variance hierarchical approach with Euclidean distance (JMP, SAS Institute), using otolith core concentrations of $\mathrm{Mg}$ and $\mathrm{Ba}$ (Standish et al. 2008). Elemental data were standardized (mean $=0, \mathrm{SD}=1$ ) prior to cluster analysis. To statistically determine the number of significant dimensions (or 'types') in the resulting overall classification, we used bootstrap resampling (see Pillar 1999). The stability of the partition at a given level was tested by resampling the original data with replacement. The result of the test indicates whether any of the groups in a cluster analysis are distinct enough to reappear more often in resampling than expected on a random basis.

\section{RESULTS}

We found significant variation between locations resulting from site differences in $\mathrm{Ba}$ and $\mathrm{Sr}$ elemental concentration in otolith cores of Coris julis (MANOVA; $F=13.39, \mathrm{p}<$ 0.0001). Discriminant function analysis (DFA) indicated spatial differentiation between sites, particularly between Varadouro and Corvo, and between these and the remaining sites $($ DFA; Pillai's trace $=0.707, \mathrm{p}<0.0001)$ (Fig. 2). Cluster analysis and bootstrap resampling revealed strong partitioning (at $\alpha=$ 0.1 ) at the level of 4 natal signature types (Fig. 3), indicating that chemical natal signature types can be identified in the otolith 
cores of recruits collected across the archipelago and at 1 island. Partitioning at lower levels (greater number of clusters) did not add to site discrimination.

Natal signature Types 1 and 4 were characterized by relatively low concentrations of both $\mathrm{Mg}: \mathrm{Ca}$ and $\mathrm{Ba}$ : $\mathrm{Ca}$, with proportionally more elevated $\mathrm{Mg}: \mathrm{Ca}$ relative to Ba:Ca in Type 1 and the opposite trend in Type 4 (Fig. 4). Type 2 was characterized by disproportionally high $\mathrm{Ba}: \mathrm{Ca}$ and intermediate $\mathrm{Mg}: \mathrm{Ca}$ concentrations, while Type 3 was distinguished by very high $\mathrm{Mg}: \mathrm{Ca}$ and intermediate Ba:Ca concentrations.

Each collection location received a mixture of natal signature types, and the proportion and diversity of the natal signature types varied among these locations (Fig. 1). At 4 out of 6 collection sites, 2 offshore seamounts (P Alice and DJC) and 2 island sites (Sta. Maria and Salão), we found a mix of Types 1, 2, and 4, in variable proportions. One individual from DJC was classified as Type 3. A very different natal type composition was found at the most northwestern site (Corvo Island),

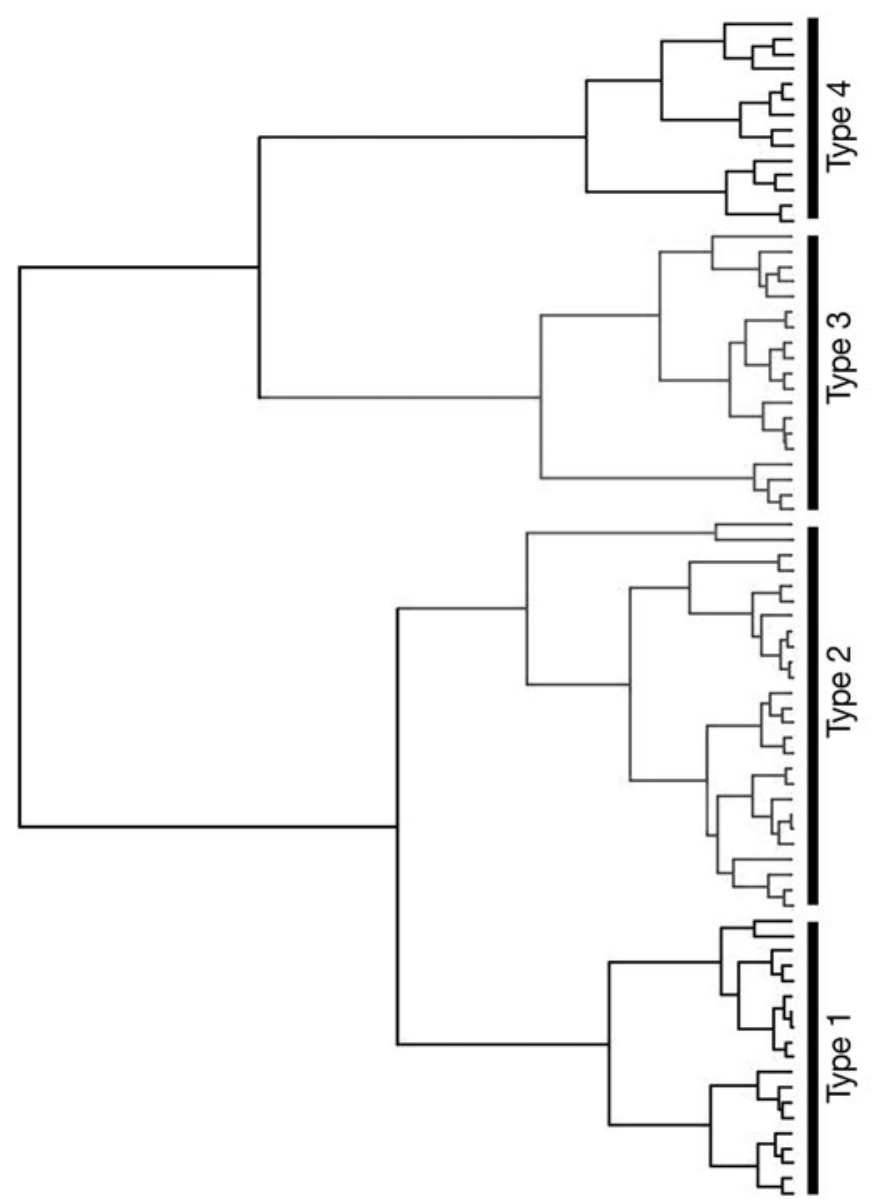

Fig. 3. Coris julis. Cluster solution using Ward's minimum variance approach to cluster analysis of otolith core chemistry recruits. Partition at the 4 -cluster level was determined by the bootstrap resampling method. For type definition see 'Results' and Fig. 4

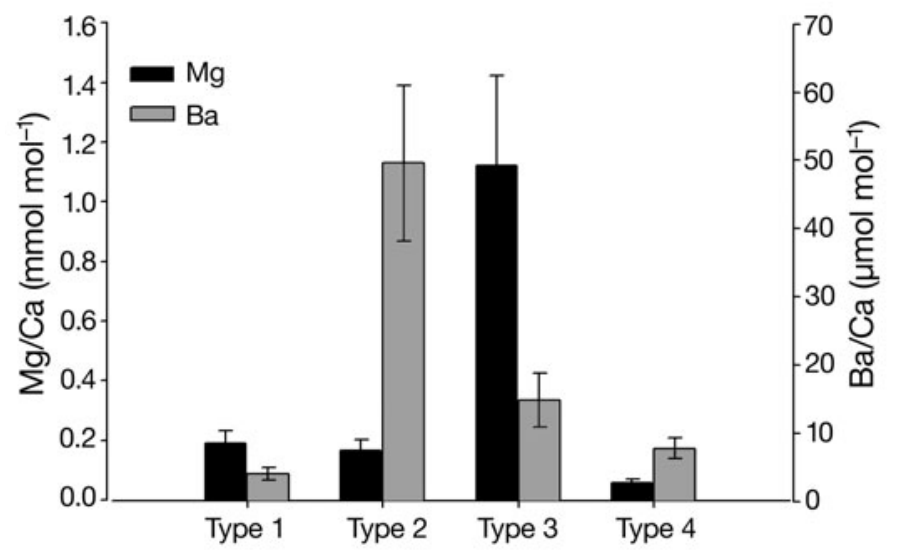

Fig. 4. Coris julis. Mean elemental concentrations $( \pm 1 \mathrm{SE})$ in recruit otolith cores grouped by natal type

where Natal Type 4 was absent and Type 1 was dominant. The most distinctive type composition was found at Varadouro (Faial Island, south shore), where the generally rare Type 3 was almost exclusively found along with a small proportion of Natal Type 1 (Fig. 1). At the smallest scale, within Faial Island, natal type composition was clearly dissimilar between south and north shore collection sites, which only shared natal signature Type 1, the least abundant natal type at both sampling locations.

Average elemental concentration trajectories from core to edge of recruits from the 2 offshore collection sites (DJC and P Alice) and the smallest island, Corvo, were typically asymmetrical, that is, average elemental concentration of at least one of the elements tended to be relatively higher or lower at the core than at the otolith edge (Fig. 5). Conversely, for recruits collected at the remaining island sites, we found that elemental concentrations along the otolith growth axis tended to be highest at the core and edge and lowest over the otolith portion corresponding to the pelagic stage. In particular, a comparison of the elemental trajectories between the 2 Faial Island sites (Varadouro and Salão; Fig. 5) suggested different pelagic dispersal histories.

\section{DISCUSSION}

In the present study, we found enough variability in trace element concentrations in the otolith cores of recently settled Coris julis from several locations to result in 4 unique natal elemental signature types. Given the impossibility of characterizing all possible sources in the region, the presence of some natal types at all sampling locations (e.g. Type 1) provides little or no useful information about population connectivity, because this pattern may result from either the settlement of recruits from multiple origins with similar 

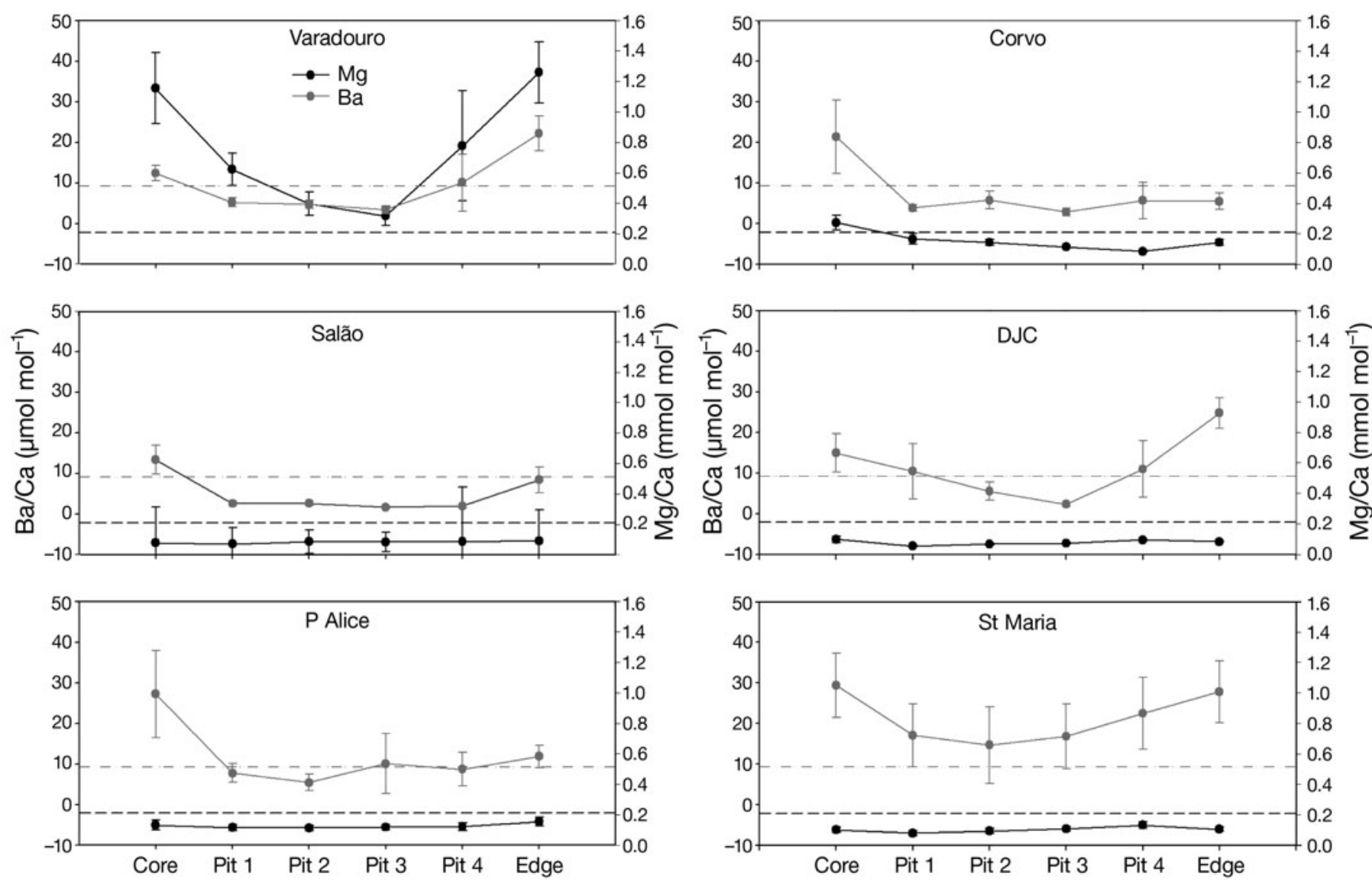

Fig. 5. Coris julis. Otolith elemental profiles depicting average Mg:Ca and Ba:Ca concentrations ( \pm 1 SE) along temporal transects (from core to edge) for recruits collected at each site. Dashed lines represent overall means for each element, black for Mg:Ca and gray for Ba:Ca concentrations. Sampling sites are shown in Fig. 1

water chemistry (identical source signatures) or from the settlement of recruits with common origin. On the contrary, differences among sites in natal type composition are more informative because they suggest multiple distinct sources of replenishment (Standish et al. 2008). This was particularly evident at the smallest scale, where most of the recruits collected at the south shore of Faial Island (Varadouro) were classified as Type 3. This natal type was not found among the north shore (Salão) recruits, or at most of the remaining sites. This particular result strongly suggests that population connectivity via larval dispersal may be more limited than expected (at the scale of 10s of kilometers) at this relatively small island. In addition, elemental profiles from core to edge are quite different for recruits collected at these 2 sites. Such differences are usually indicative of the presence of dissimilar water masses encountered during pelagic development, thus suggesting different larval sources (Patterson et al. 2005). Nevertheless, until more information on the spatial scale of the source populations is available, we must consider the possibility that, although multiple natal types likely correspond to different geographical origins, such sources may not necessarily correspond to demographically distinct populations (see Warner et al. 2005, Ruttenberg \& Warner 2006).

We also found that both the cores and edges of Varadouro recruit otoliths were enriched in Mg, suggesting that these larvae hatched and settled in relatively Mg-enriched water, possibly in the same water mass. If this is true, our findings are in line with the emerging view that larval dispersal and population connectivity may be more limited than previously thought. Evidence is accumulating for self-recruitment occurring over scales as small as individual reefs (e.g. Jones et al. 1999, Swearer et al. 1999, Cowen et al. 2006, Almany et al. 2007). Elevated otolith elemental profiles, from core to post-settlement, with relatively high concentrations during the larval phase, have been associated with local larval retention of other wrasses (e.g. Swearer et al. 1999, Hamilton et al. 2008). Although average $\mathrm{Mg}$ :Ca levels tended to drop between the otolith core and edge, following an expected trend (Ruttenberg et al. 2005), the middle portion of the oto- 
liths of Varadouro recruits was still more enriched relative to those at other sites. The massive deposits of sand and ash on the Capelinhos volcano, rich in $\mathrm{MgO}$ (Torre de Assução 1959), are exposed to continuous wave, rain, and wind erosion. The resulting persistent runoff and the predominant west and northwest swells (Carvalho 2003) suggest that Capelinhos could be the natural source of $\mathrm{Mg}$ for Varadouro recruits. Preliminary data from a tidal circulation model also suggest that Varadouro Bay is on the island lee (M. Juliano pers. comm.), where a higher potential for larval retention is expected (Swearer et al. 2002). Tempera (2008) also found negative anomalies of sea surface temperature (SST) and positive anomalies of chlorophyll a (AVHRR) for this inshore area, further supporting this argument.

Recent studies have documented extensive variation in natal signatures among broods within a site or region (Warner et al. 2005, Zacherl 2005, Ruttenberg \& Warner 2006). If sufficiently strong, among-brood differences could confound the interpretations of the spatial analysis of natal types by producing distinct natal types that reflect differences between broods within a location rather than the contribution of distinct source locations (Standish 2007). The Varadouro recruits used in the present study were collected on 2 sampling dates almost a month apart, and are likely 2 different cohorts. Despite this, almost all recruits from Varadouro were classified as Natal Type 3, suggesting some temporal continuity of natal origin and water chemistry conditions at the natal origin. If maternal provisioning affects the chemistry of natal otoliths, internal brooders (like rockfish, genus Sebastes) or species that lay larger benthic eggs (such as damselfish, Stegastes beebei) may have stronger maternal effects than those with smaller pelagic eggs, such as Coris julis, but this idea has yet to be tested explicitly (Ruttenberg \& Warner 2006).

At the larger scale (100s of kilometers), we found an important difference in natal type composition between the northwesternmost island Corvo and the remaining southeastern sites: Natal Type 4 was absent in Corvo. This result is consistent with the hypothesis that Corvo does not rely on the source or sources of Natal Type 4, which appear to significantly contribute to most southeastern sites (Sta. Maria, DJC, P Alice, Salão). Larval dispersal patterns are likely to be a result of many factors, including ocean currents and larval behavior (Schmitt \& Holbrook 2002, Cowen et al. 2006). The mid-Atlantic Ridge is a potential barrier to larval dispersal along the Azores, because it separates Corvo, on the warmer western ocean basin, from the remaining sites located on the colder eastern sub-tropical ocean basin (Bashmachnikov et al. 2004). This means that oceanographically, Corvo is partially isolated from the remaining sampled locations, which could explain the differences found in natal type composition.

Aurelle et al. (2003) detected some genetic differentiation between Coris julis populations from Corvo and Sta. Maria (although these differences were statistically non-significant after sequential Bonferroni correction). Stockley et al. (2005) also suggested some restriction of gene flow for Pagellus bogaraveo between the western islands and the rest of the archipelago, though evidence for this is weak. Genetic approaches may not have sufficient resolution to quantify natal homing unless straying is negligible over evolutionary time scales (Thorrold et al. 2001).

While the absence of unique natal elemental types at given locations can provide information regarding barriers to larval dispersal, similarities in the natal signature types, such as those we found from Salão to Sta. Maria, do not provide unequivocal information regarding dispersal patterns or contributing sources (Standish 2007). Although not conclusive, the elemental trajectories found along the otolith growth axis and, in particular, the differences in Ba:Ca concentration between the core and edge suggest that some proportion of the recruits to the 2 offshore reefs (DJC and P Alice) and Corvo were probably not produced locally. Such a pattern may arise when the water chemistry at the natal origin of recruits has a different geochemical signature relative to the place of settlement.

The fact that we found more variable otolith natal type composition over the smallest scale (10s of kilometers) relative to the broad scale (100s of kilometers) is not surprising. Recent work by Ruttenberg \& Warner (2006), comparing the chemistry of natal otoliths of a damselfish Stegastes beebei from the Galapagos Islands, also found little natal elemental variation at the largest scale $(100 \mathrm{~km})$, despite the significant differences found at smaller scales (10s of kilometers). This result highlights the importance of matching the study scale with the scale of chemical variation and the dispersal scale of the study organism when using otolith chemistry to track larval dispersal (Ruttenberg \& Warner 2006).

In summary, the present study demonstrates the use of natal elemental signatures in the otolith cores of fish recruits to examine larval dispersal patterns among and at individual islands. Natal elemental signatures in the otolith cores of Coris julis varied sufficiently to produce distinct geochemical signature types. The spatial pattern of natal elemental types revealed that locations along the archipelago received a mixture of natal types, suggesting that a number of sources contributed to recruitment. Moreover, we found strong differences in the occurrence of specific natal types at small scales (10s of kilometers), suggesting limited connectivity at a relatively small island. 
Acknowledgements. We sincerely thank B. Ruttemberg, F. Cardigos, G. Paradis, J. Barr, J. Standish, R. Bettencourt, R. Ferraz, N. Serpa, S. Hamilton, and RV 'Arquipélago' and RV 'Águas Vivas' crews for helping with sample collections and laboratory work. For individual support, J. Fontes thanks FCT/MCTES (SFRH/BD/12788/2003 and FLAD). IMAR-DOP is UI\&D No. 531 funded through the Programmatic and Pluriannual programs of FCT/MCTES and Azorean DRCT, part FEDER. This paper is a contribution to MAREFISH (FCT - POCTI/BSE/41207/2001) and MARMACII (INTERREG/05/MAC/4.2/A4).

\section{LITERATURE CITED}

Afonso P (2002) Spatial patterns in the littoral fish community of the Azores. MS thesis, University of Coimbra, Coimbra

Almany GR, Berumen ML, Thorrold SR, Planes S, Jones GP (2007) Local replenishment of coral reef fish populations in a marine reserve. Science 316:742-744

- Amorim P, Figueiredo M, Machete M, Morato T, Martins A, Santos RS (2009) Spatial variability of seabird distribution associated with environmental factors: a case study of marine Important Bird Areas in the Azores. ICES J Mar Sci 66:29-40

Ashford JR, Arkhipkin AI, Jones CM (2006) Can the chemistry of otolith nuclei determine population structure of Patagonian toothfish Dissostichus eleginoides? J Fish Biol 69:708-721

Aurelle D, Guillemaud T, Afonso P, Morato T, Wirtz P, Santos RS, Cancela ML (2003) Genetic study of Coris julis (Osteichtyes, Perciformes, Labridae) evolutionary history and dispersal abilities. C R Biol 326:771-785

Bashmachnikov I, Lafon V, Martins A (2004) SST stationary anomalies in the Azores region. Proc SPIE 5569:148-155

Campana SE, Neilson JD (1985) Microstructure of fish otoliths. Can J Fish Aquat Sci 42:1014-1032

> Campana SE, Fowler AJ, Jones CM (1994) Otolith elemental fingerprinting for stock identification of Atlantic cod (Gadus morhua) using laser-ablation ICPMS. Can J Fish Aquat Sci 51:1942-1950

Carvalho F (2003) Elementos do clima de agitação marítima no Grupo Central dos Açores (Mar Alto). Instituto de Meteorologia, Lisbon

Cowen RK, Sponaugle S (2009) Larval dispersal and marine population connectivity. Annu Rev Mar Sci 1:444-466

- Cowen RK, Paris CB, Srinivasan A (2006) Scaling of connectivity in marine populations. Science 311:522-527

DiBacco C, Levin LA (2000) Development and application of elemental fingerprinting to track the dispersal of marine invertebrate larvae. Limnol Oceanogr 45:871-880

FitzGerald JL, Thorrold SR, Bailey KM, Brown AL, Severin KP (2004) Elemental signatures in otoliths of larval walleye pollock (Theragra chalcogramma) from the northeast Pacific Ocean. Fish Bull (Wash DC) 102:604-616

$>$ Forrester GE, Swearer SE (2002) Trace elements in otoliths indicate the use of open-coast versus bay nursery habitats by juvenile California halibut. Mar Ecol Prog Ser 241:201-213

Fowler AJ, Gillanders BM, Hall KC (2005) Relationship between elemental concentration and age from otoliths of adult snapper (Pagrus auratus, Sparidae): implications for movement and stock structure. Mar Freshw Res 56:661-676

Hamilton SL, Regetz J, Warner RR (2008) Postsettlement survival linked to larval life in a marine fish. Proc Natl Acad Sci USA 105:1561-1566

Jones GP, Milicich MJ, Emslie MJ, Lunow C (1999) Selfrecruitment in a coral reef fish population. Nature 402: 802-804
Kinlan BP, Gaines SD (2003) Propagule dispersal in marine and terrestrial environments: a community perspective. Ecology 84:2007-2020

- Klein B, Siedler G (1989) On the origin of the Azores current. J Geophys Res B 94:6159-6168

> Leis JM, Carson-Ewart BM (1998) Complex behaviour by coral-reef fish larvae in open-water and near-reef pelagic environments. Environ Biol Fishes 53:259-266

Miller TJ, Shanks A (2004) Evidence for limited larval dispersal in black rockfish (Sebastes melanops): implications for population structure and marine-reserve design. Can J Fish Aquat Sci 61:1723-1735

> Monteiro LR, Ramos JA, Furness RW, DelNevo AJ (1996) Movements, morphology, breeding, molt, diet and feeding of seabirds in the Azores. Colon Waterbirds 19:82-97

Morato T, Varkey DA, Dâmaso C, Machete M and others (2008) Evidence of a seamount effect on aggregating visitors. Mar Ecol Prog Ser 357:23-32

Patterson HM, Kingsford MJ, McCulloch MT (2005) Resolution of the early life history of a reef fish using otolith chemistry. Coral Reefs 24:222-229

Patzner RA, Santos RS (1993) Ecology of rocky littoral fishes of the Azores. Cour Forschungsinst Senckenb 159:423-427

Pillar VD (1999) How sharp are classifications? Ecology 80: $2508-2516$

Raventos N, Macpherson E (2001) Planktonic larval duration and settlement marks on the otoliths of Mediterranean littoral fishes. Mar Biol 138:1115-1120

Ruttenberg BI, Warner RR (2006) Spatial variation in the chemical composition of natal otoliths from a reef fish in the Galapágos Islands. Mar Ecol Prog Ser 328:225-236

> Ruttenberg BI, Hamilton SL, Hickford MJH, Paradis GL and others (2005) Elevated levels of trace elements in cores of otoliths and their potential for use as natural tags. Mar Ecol Prog Ser 297:273-281

> Ruttenberg BI, Hamilton SL, Warner RR (2008) Spatial and temporal variation in the natal otolith chemistry of a Hawaiian reef fish: prospects for measuring population connectivity. Can J Fish Aquat Sci 65:1181-1192

Sale PF, Cowen RK, Danilowicz BS, Jones GP and others (2005) Critical science gaps impede use of no-take fishery reserves. Trends Ecol Evol 20:74-80

> Santos RS, Hawkins S, Monteiro LR, Alves M, Isidro EJ (1995) Marine research, resources and conservation in the Azores. Aquat Conserv Mar Freshw Ecosyst 5:311-354

Schmitt RJ, Holbrook SJ (2002) Correlates of spatial variation in settlement of two tropical damselfishes. Mar Freshw Res 53:329-337

Secor DH, Rooker JR, Zlokovitz E, Zdanowicz VS (2001) Identification of riverine, estuarine, and coastal contingents of Hudson River striped bass based upon otolith elemental fingerprints. Mar Ecol Prog Ser 211:245-253

Standish JD (2007) Use of otolith trace-elemental signatures to identify larval connectivity and dispersal patterns in a temperate marine fish. PhD thesis, University of California, Santa Barbara, CA

- Standish JD, Sheehy M, Warner RR (2008) Use of otolith natal elemental signatures as natural tags to evaluate connectivity among open-coast fish populations. Mar Ecol Prog Ser 356:259-268

> Stockley B, Menezes G, Pinho MR, Rogers AD (2005) Genetic population structure in the black-spot sea bream (Pagellus bogaraveo Brunnich, 1768) from the NE Atlantic. Mar Biol 357:793-804

Swearer SE, Caselle JE, Lea DW, Warner RR (1999) Larval retention and recruitment in an island population of a coral-reef fish. Nature 402:799-802 
Swearer SE, Shima JS, Hellberg ME, Thorrold SR and others (2002) Evidence of self-recruitment in demersal marine populations. Bull Mar Sci 70:251-271

Tempera F (2008) Benthic habitats of the extended Faial Island shelf and their relationship to geologic, oceanographic and infralittoral biologic features. PhD thesis, University of St. Andrews, St. Andrews

Thorrold SR, Jones CM, Campana SE (1997) Response of otolith microchemistry to environmental variations experienced by larval and juvenile Atlantic croaker (Micropogonias undulatus). Limnol Oceanogr 42:102-111

Thorrold SR, Latkoczy C, Swart PK, Jones CM (2001) Natal homing in a marine fish metapopulation. Science 291: 297-299

Editorial responsibility: Nicholas Tolimieri, Seattle, Washington, USA
Torre de Assução CF (1959) Contribuição para a petrografia dos produtos emitidos pelo vulcão dos Capelinhos (Faial). In: Le Volcanisme de l'île de Faial et l'Éruption du Volcan de Capelinhos. Direcção Geral de Minas e Seviços Geológicos, Lisbon, p 57-64

Warner RR, Cowen RK (2002) Local retention of production in marine populations: evidence, mechanisms, and consequences. Bull Mar Sci 70:245-249

Warner RR, Swearer SE, Caselle JE, Sheehy M, Paradis G (2005) Natal trace-elemental signatures in the otoliths of an open-coast fish. Limnol Oceanogr 50:1529-1542

Zacherl DC (2005) Spatial and temporal variation in statolith and protoconch trace elements as natural tags to track larval dispersal. Mar Ecol Prog Ser 290:145-163

Submitted: February 10, 2009; Accepted: May 15, 2009 Proofs received from author(s): July 21, 2009 